Check for updates

Cite this: RSC Adv., 2019, 9, 15874

Received 11th February 2019

Accepted 4th May 2019

DOI: $10.1039 / c 9 r a 01072 f$

rsc.li/rsc-advances

\section{Bio-fabrication of pigment-capped silver nanoparticles encountering antibiotic-resistant strains and their cytotoxic effect towards human epidermoid larynx carcinoma (HEp-2) cells}

\author{
Lakshmipathy Muthukrishnan, ${ }^{a}$ Muralidharan Chellappa, ${ }^{a}$ Anima Nanda, ${ }^{b}$ \\ Sudhakar Thukkaram, ${ }^{\text {b }}$ Gracyfathima Selvaraj, ${ }^{\mathrm{c}}$ Bavanilatha Muthiah, ${ }^{\mathrm{b}}$ \\ Suresh Sagadevan (D)*d and J. Anita Lett (D) ${ }^{\mathrm{e}}$
}

\begin{abstract}
Bacterial biomolecule-mediated nanoparticle (NP) synthesis constitutes a reliable, eco-friendly approach that ameliorates green-chemistry principles. In this study, stable silver nanoparticles were synthesized by exposing aqueous silver ions to an extracellular diffusible pigment produced by Pseudomonas aeruginosa (PA6) under optimized laboratory conditions. Spectroscopic and microscopic analyses showed the typical characteristics of silver with an average size of $\sim 28.30 \mathrm{~nm}$ and spherical shape. The particles were polydispersed and showed no definite agglomeration with a zeta potential of $-32.3 \mathrm{mV}$, conferring stability. Antimicrobial studies were carried out using 5, 15, 25 and $50 \mu \mathrm{g} \mathrm{mL}^{-1}$ concentrations of pcAgNPs, which showed significant antibacterial activity toward clinically important pathogens at all concentrations compared to with the control sample. The bactericidal effect induced by pcAgNPs associated with cell damage was well demonstrated using electron microscopic studies. ROS production was measured using the DCFH-DA method and the oxidative stress was assessed by measuring the reduced glutathione (GSH) levels. Cytotoxicity studies on HEp-2 (Human Epidermoid Larynx Carcinoma) cells exposed to pcAgNPs showed dose-dependent cytotoxic effect with $\mathrm{IC}_{50}$ of $14.8 \mu \mathrm{g} \mathrm{mL}{ }^{-1}$ compared to with $\mathrm{IC}_{50}$ of $7.38 \mu \mathrm{g} \mathrm{mL}{ }^{-1}$ for the Vero cell control. Mechanistically, the pcAgNPs activated p53 that induced catalase, leading to apoptosis and DNA fragmentation via a p53 transcriptional pathway and electron transport arrest, which resulted in cell death. This synergistic efficacy of pigment-AgNPs demonstrated excellent antimicrobial and anti-proliferative activities, providing a potential lead for developing a broad-spectrum antibacterial agent and improving the therapeutic modalities targeting carcinoma cells at the gene level.
\end{abstract}

\section{Introduction}

Nanotechnology, a major recent technological development, has experienced tremendous growth in the fabrication of materials at a sub-atomic scale for more precise and unique functionalities. ${ }^{1}$ Such engineered nanomaterials have extended

${ }^{a}$ Leather Process Technology, Tannery Division, CSIR - Central Leather Research Institute (CLRI), Adyar, Chennai, Tamilnadu 600 020, India. E-mail: mlakshmipathy@gmail.com

${ }^{b}$ Faculty of Bio \& Chemical Engineering, Sathyabama Institute of Science and Technology (Deemed to be University), Rajiv Gandhi Salai, Chennai, Tamilnadu 600119, India

'Department of Virology, King Institute of Preventive Medicine and Research, Guindy, Chennai, Tamilnadu 600 032, India

${ }^{d}$ Nanotechnology \& Catalysis Research Centre (NANOCAT), University of Malaya, Kuala Lumpur 50603, Malaysia. E-mail: drsureshnano@gmail.com

${ }^{e}$ Department of Physics, Sathyabama Institute of Science and Technology, Chennai600119, India its potential therapeutic and preventive applications in the biomedical and clinical fields. Specifically, the influence of their size extends their ability to surpass physiological barriers and affinity toward the cellular components of biological origin, allowing them to access the most complicated bio-molecular systems. ${ }^{2}$ Moreover, nanoparticles are being used as antimicrobial agents and vehicles for targeted delivery, ${ }^{3}$ gene therapy, ${ }^{4}$ and cell labeling. ${ }^{5}$

Despite several breakthroughs in the formulation of specialist drugs from leading pharma on par with the increasing incidences of infectious diseases, a push for defending the scope of nanotechnology toward bio-clearance remains vital. As the use of conventional antibiotics rises, antimicrobial resistance patterns develop, ${ }^{6}$ demanding a continuous need for novel and more effective therapies. ${ }^{7}$ To date, nanotechnology-driven bio-pharmaceuticals have been the focus of many investigations and remain one of the highly specialized alternative medicines for curing chronic diseases 
such as cancer. ${ }^{8}$ Although many studies have focused on nanoparticle-induced cytotoxicity and the corresponding mechanisms, ${ }^{9}$ the decisive factors and accompanying changes involved in cytotoxicity remain unclear. ${ }^{10}$ It is noteworthy that several genes participate in the induction of apoptosis, but the role of the p53 pathway that determines the fate of cancerous cells has rarely been studied. Moreover, in more than half of human cancers, the tumor-suppressing p53 gene remains dormant. ${ }^{11}$ Thus, there is a great interest aimed at developing therapeutic strategies to overcome drug resistance in microbial communities and to anticipate the role of p53 for a prolonged expression through the nanoparticulate system. ${ }^{12}$

To solve the above-mentioned issues, research studies on synthesizing nanomaterials that exhibit excellent pharmacodynamic and pharmacokinetic properties in an eco-friendly fashion and following the green chemistry principle have been proposed. ${ }^{13}$ Besides chemical and physical methods, the bioprocess-mediated synthesis of nanomaterials is a fascinating approach for the development of a nanoparticle-biomolecule conjugate. ${ }^{\mathbf{1 4 1 5}}$ This is achieved using biocatalysts and/or metabolites such as pigments, toxins, and siderophores, exhibiting phenomenal characteristics such as virulence, defense mechanism, and stress. ${ }^{16}$ In recent years, pigments of microbial origin, especially those produced by Pseudomonads, are gaining much importance in the food and agriculture sector as bio-control agents. The exploitation of such bacteria for their catabolic versatility and broad-spectrum antibiosis can help improve crop production. ${ }^{17,18}$

In this study, we present an eco-friendly approach for synthesizing silver nanoparticles harnessing a versatile pigment produced by $P$. aeruginosa in a reliable, stable and cost-effective manner. We investigated the biological role of the bacterial pigment-capped AgNPs toward containing antibiotic-resistant strains and the in vitro antiproliferative effect with respect to the p53 expression using the human epidermoid larynx carcinoma cell line (HEp-2).

\section{Materials and methods}

\subsection{Isolation of Pseudomonas aeruginosa}

The bacterium used for the synthesis of silver nanoparticles was isolated from rhizosphere soil samples collected from the paddy fields (Lat. $12^{\circ} 54^{\prime} 40^{\prime \prime} \mathrm{N}$ and Long. $79^{\circ} 8^{\prime} 10^{\prime \prime} \mathrm{E}$ ) in Vellore, Tamilnadu, India. The pseudomonas strains were isolated by performing a dilution plate technique ${ }^{19}$ on Pseudomonas isolation agar (cat no. 17208, Sigma-Aldrich, USA), and the plates were incubated at $37 \pm 2{ }^{\circ} \mathrm{C}$ for $24 \mathrm{~h}$. Prior to incubation, the plates were observed for any growth on the selective media. The isolated colonies of the Pseudomonas species were further purified by quadrant streaking on Cetrimide Agar (cat. no. 22470, SigmaAldrich, USA) plates and maintained at $4{ }^{\circ} \mathrm{C}$.

\subsection{Molecular identification of the potential strain}

The growth characteristics of the bacterial isolates, viz., lactose fermentation, odour, and pigmentation were observed along with the standard biochemical tests and identified based on
Bergey's manual of determinative bacteriology. ${ }^{20}$ For identification at the molecular level, the total DNA from the potential strain was extracted using a MagAttract Microbial DNA kit (cat. no. 27200.4, Qiagen) and the 16S ribosomal RNA gene was amplified using PCR with suitable primers. The PCR product obtained was sequenced by an automated sequencer ABI PRISM (Model 3700) and the sequences were compared using the BLAST program (http://www.ncbi.nlm.nih.gov/BLAST/).

\subsection{Pigment production}

First, 35 pseudomonas strains obtained from various sites were used for the production, extraction, and characterization of pigment, and the conditions were optimized as described in our previous study. ${ }^{21}$ In brief, the isolates were inoculated into Erlenmeyer flasks containing $100 \mathrm{~mL}$ of Pseudomonas broth (cat. no. Z699101, Sigma-Aldrich, USA) and incubated at $37^{\circ} \mathrm{C}$ in a rotary shaker for $24 \mathrm{~h}$ till the color changed. The pigment produced by the potential strain was quantified based on the absorbance of the pigment in the acidic form at $520 \mathrm{~nm}$ and the concentration was determined using the following formula according to Essar et al. (1990): ${ }^{22}$

$$
\text { concentration }\left(\mu \mathrm{g} \mathrm{mL}^{-1}\right)=\text { O. } \mathrm{D}_{520} \times 17.07
$$

The strain that showed the maximum pigment production prior to incubation was retained for synthesizing AgNPs.

\subsection{Bio-synthesis of AgNPs using potential strain}

The preliminary screening process was performed by taking $10 \mathrm{~mL}$ of the diffusible pigment of the strain and adding it to $90 \mathrm{~mL}$ of $10^{-3} \mathrm{M} \mathrm{AgNO}_{3}$ (CAS No. 7761-88-8, Sigma-Aldrich, USA) in Erlenmeyer flasks till 1:1 concentration was achieved. The flasks were examined visually for any colour change prior to the reaction period at $37{ }^{\circ} \mathrm{C}$ and $150 \mathrm{rpm}$, which was indicative of nanoparticle formation. After the formation of nanoparticles, the flasks were removed from the shaker and centrifuged at $8000 \mathrm{rpm}$ for $20 \mathrm{~min}$, freeze-dried and quantified. $^{23}$

\subsection{Optimization studies on AgNP synthesis}

The ideal conditions for nanoparticle synthesis were optimized by varying the physicochemical parameters such as the temperature $\left(10,20,30,40\right.$ and $\left.50{ }^{\circ} \mathrm{C}\right), \mathrm{pH}(2-9)$, the concentration of the substrate $\left(0.5-2 \mathrm{mM} \mathrm{AgNO}_{3}\right)$ and the reaction period (0-72 h). Sampling was performed by withdrawing $1 \mathrm{~mL}$ aliquots at different time intervals; these aliquots were subjected to spectrophotometric analysis. ${ }^{24}$

\subsection{Characterization of pcAgNPs}

A UV-visible spectrophotometer model UV-1800 (Shimadzu) was used to record the absorption spectra of the reaction mixture. The reduction of silver ions was monitored by the random sampling of a $1 \mathrm{~mL}$ aliquot in a quartz cuvette and detected in the scanning range of $800-200 \mathrm{~nm}$ at a resolution of $1 \mathrm{~nm}$. The pcAgNPs were separated and saturated by repeated washing and 
centrifugation at $15000 \mathrm{rpm}$ for $20 \mathrm{~min}$ and the final suspension was freeze-dried. Powder X-ray diffraction patterns were measured on a Rigaku multiflex diffractometer that operated at $30 \mathrm{kV}$ and $100 \mathrm{~mA}$ at $3 \mathrm{~kW}$ with a $\mathrm{Cu}$ target $\mathrm{K} \alpha$ radiation using a scintillation counter $(\lambda=1.5418 \AA)$. For FT-IR analysis, the freeze-dried pcAgNPs were diluted with potassium bromide in a ratio of $1: 100$ and the spectrum was recorded on a JASCO 4400 model in a diffused reflectance mode in the region of $4000-400 \mathrm{~cm}^{-1}$ and at a resolution of $4 \mathrm{~cm}^{-1}$. HR-TEM (Philips CM200) and SAED were performed to identify the size and shape of the nanoparticles. The pcAgNP samples used for microscopic analyses were prepared on a carbon-coated copper grid. ${ }^{24,25}$

The particle size and distribution of the bio-synthesized silver nanoparticles were observed using dynamic light scattering (DLS) (Malvern Zetasizer, ver. 6.2). For this experiment, the samples were measured at a fixed angle of $90^{\circ}$ at room temperature and the intensity was adjusted in the range of 50$500 \mathrm{kcps}$ by diluting with deionized water. The zeta potential of the silver nanoparticles was also measured by following the above-mentioned protocol and the measurements were analyzed in triplicate.

Atomic force microscopy was employed to study the topography at the nanoscale. The sample was prepared by dissolving pcAgNPs in ethanol and sonicating (Vibra cell, Sonics) to prevent aggregation. Ten $\mu \mathrm{L}$ of the sample was casted onto a silicon slide and the solvent was allowed to evaporate. Then, the thin film of size $1 \mathrm{~cm} \times 1 \mathrm{~cm}$ was imaged in the tapping mode with a spring constant of $0.41 \mathrm{~N} \mathrm{~m}^{-1}$ and resonance frequency $18 \mathrm{kHz}$ via AFM (Ntegra Prima - NTMDT, Ireland).

\subsection{Antibacterial activity of pcAgNPs against clinical isolates}

Bacterial strains showing resistance toward two different groups of commonly used antibiotics, viz., Methicillin-resistant Staphylococcus aureus (MRSA), Staphylococcus epidermidis (MRSE), Proteus mirabilis, E. coli, Klebsiella pneumoniae, Acinetobacter baumannii, and the vancomycin-resistant Enterococci were used for antibacterial studies. The clinical isolates were procured from $\mathrm{M} \mathrm{s}^{-1}$. Sharp Laboratories, Chennai, Tamilnadu, and the pure cultures were maintained in Muller Hinton agar (MHA, HiMedia ${ }^{\mathrm{TM}}$, India) slants at $4{ }^{\circ} \mathrm{C}$. The antibacterial activity of pcAgNPs was tested against these drug-resistant bacterial strains using the Kirby Bauer's disk diffusion method. ${ }^{26,27}$ Sterile disks (HiMedia ${ }^{\mathrm{TM}}$, India) containing 5, 15, 25 and $50 \mu \mathrm{g} \mathrm{mL}^{-1}$ of pcAgNPs were prepared and placed on MHA plates using sterile forceps along with $1 \mathrm{mM} \mathrm{AgNO}_{3}$ as the control. The zone of inhibition (ZOI) was measured after incubation at $37{ }^{\circ} \mathrm{C}$ for $18-24 \mathrm{~h}$ and compared with that of the control.

To detect the membrane damage, different volumes of the MH medium, pcAgNPs and the most susceptible strains $\left(10^{5}\right.$ CFU mL ${ }^{-1}$ ) were added to $5 \mathrm{~mL}$ broth with a final concentration of $25 \mu \mathrm{g} \mathrm{mL}{ }^{-1}$ AgNPs. Control experiments were conducted without AgNPs. The cultures were incubated at $37 \pm 2{ }^{\circ} \mathrm{C}$ with shaking at $150 \mathrm{rpm}$. One hundred microlitres of cultures were sampled after being treated for 2 to $4 \mathrm{~h}$. The cultures were centrifuged at $8000 \mathrm{rpm}$, the supernatant was discarded, and the cells were fixed for observation by scanning electron microscopy. ${ }^{28}$

\subsection{ROS production and glutathione (GSH) measurements}

The intracellular localization of stress-induced reactive oxygen species (ROS) was estimated by $2^{\prime}, 7^{\prime}$-dichlorodihydrofluorescein diacetate (DCFH-DA, cat no. D6883, Sigma-Aldrich, USA) as described. ${ }^{29}$ The strains were selected based on the antibiogram pattern representing Gram-positive and Gram-negative bacteria. These cells at $10^{5} \mathrm{CFU} \mathrm{mL}{ }^{-1}$ were incubated at $37{ }^{\circ} \mathrm{C}$ with DCFH-DA $(0.5 \mathrm{mM})$ for $30 \mathrm{~min}$, followed by the addition of pcAgNPs $\left(5,15,25,50 \mu \mathrm{g} \mathrm{mL}^{-1}\right)$. The bacterial cells were further incubated for $4 \mathrm{~h}$ at $37^{\circ} \mathrm{C}$ and the fluorescence emission was recorded at $523 \mathrm{~nm}$ with excitation at $503 \mathrm{~nm}$ on a Jobin Yvon Flurolog-3-11 spectrofluorometer. The ROS production was interpreted from the emission intensity of the treated cells and compared against those of the negative (untreated) and positive (1 $\mathrm{mM} \mathrm{H}_{2} \mathrm{O}_{2}$ ) controls.

The intracellular GSH level was determined following the protocol of Park et al. with slight modifications. ${ }^{30}$ In short, the cells $\left(10^{5} \mathrm{CFU} \mathrm{mL}{ }^{-1}\right)$ treated with $5,15,25$ and $50 \mu \mathrm{g} \mathrm{mL}^{-1}$ AgNPs were collected and lysed with a $0.6 \% 5$-sulfosalicylic acid solution for $10 \mathrm{~min}$ on ice. Fifty $\mu \mathrm{L}$ of the cell lysate was mixed with $450 \mu \mathrm{L}$ of $\mathrm{KH}_{2} \mathrm{PO}_{4} /$ EDTA buffer $(0.1 \mathrm{M}$ potassium phosphate with $5 \mathrm{mM}$ EDTA, pH 8.0) and $100 \mu \mathrm{L}$ of $1 \mathrm{mg} \mathrm{mL}{ }^{-1} o^{-}$ phthaldialdehyde solution and incubated for $60 \mathrm{~min}$ in dark at room temperature. The fluorescence was measured on a Jobin Yvon Flurolog-3-11 spectrofluorometer with excitation and emission wavelengths of $350 \mathrm{~nm}$ and $420 \mathrm{~nm}$, respectively, and compared against that of controls as described. The concentration of GSH was determined from the standard curve and expressed in $\mathrm{mM}$.

\subsection{In vitro antiproliferative activity of pcAgNPs}

2.9.1. Culturing of cells. Human epidermoid larynx carcinoma cells (HEp-2) and Vero (African green monkey kidney epithelial cells) cells were procured from the King Institute of Preventive Medicine and Research, Guindy, Tamilnadu. They were sub-cultured under standard conditions in DMEM (cat. no. 5796, Sigma-Aldrich, USA) supplemented with 10\% FBS (cat. no. F2442, Sigma-Aldrich, USA) and $100 \mathrm{U} \mathrm{mL}^{-1}$ of penicillinstreptomycin antibiotic (cat. no. P4333, Sigma-Aldrich, USA) solutions in a humidified incubator (MCO-18AIC, Sanyo) at $37{ }^{\circ} \mathrm{C}$ with $5 \% \mathrm{CO}_{2}$.

2.9.2. Cytotoxicity of pcAgNPs-MTT assay. The MTT cell proliferation assay is a colorimetric assay for measuring cell viability through increased metabolic events, leading to the reduction of tetrazolium salt. ${ }^{31}$ Vero and HEp-2 cells at a concentration of $1 \times 10^{5}$ cells per well in 96-well plates were grown and incubated with pcAgNPs at various concentrations $\left(0.75,1.5,3.1,6.2,12.5,25,50\right.$ and $\left.100 \mu \mathrm{g} \mathrm{mL}{ }^{-1}\right)$ at $37{ }^{\circ} \mathrm{C}$ with $5 \% \mathrm{CO}_{2}$ for $24 \mathrm{~h}$. MTT ( $5 \mathrm{mg} \mathrm{mL}^{-1}$ ) (TC191, HiMedia ${ }^{\mathrm{TM}}$, India) was added to the incubated cells and further incubated for $4 \mathrm{~h}$. The purple formazan crystals formed were dissolved in $200 \mu \mathrm{L}$ of DMSO (cat. no. TC185, HiMedia ${ }^{\mathrm{TM}}$, India) and the 
absorbance was measured in an ELISA reader at $570 \mathrm{~nm}$ with the reference filter set at $655 \mathrm{~nm}$. The experiment was performed in triplicate and the data were expressed as mean $\pm \mathrm{SD}$ (standard deviation) of the concentration of pcAgNPs.

2.9.3. Apoptotic assays (AO/EB staining). Acridine orange/ ethidium bromide $(\mathrm{AO} / \mathrm{EB})$ staining was carried out to detect the morphological evidence of apoptosis on the nanoparticletreated HEp-2 cells. ${ }^{32}$ Initially, the cells were fixed in methanol and glacial acetic acid $(3: 1)$ for $1 \mathrm{~h}$ at room temperature. After incubation, the cells were stained with AO and EB $(1: 1)$ in PBS and incubated for $5 \mathrm{~min}$; then, they were washed with PBS to remove the excess unbinding dye. The stained cells were visualized under UV illumination using the $40 \times$ objective (Nikon Eclipse TS100) and the digitized images were captured.

\subsection{Semi-quantitative RT-PCR analysis}

Total RNA was extracted from the experimental cells using the Trizol reagent (TRI, Sigma-Aldrich, St. Louis, USA) kit. The RNA isolated from the cells was reverse-transcribed and amplified using the one-step RT-PCR System (Fermentas, USA). The primer sequences of the forward and reverse p53 were $5^{\prime}$ TTGAGGTGCATGTTTGTGCC-3' and ${ }^{\prime} 5^{\prime}$ AGgAGCTGGTGTTGTTGGAC- $3^{\prime}$; for $\beta$-actin, they were $5^{\prime}$ TTCCTCCCTGGAGAAGAGCTA- $3^{\prime}$ and $5^{\prime}$-CACAGAGTACTTGCGCTCAG-3', respectively.

The PCR conditions were as follows: $94{ }^{\circ} \mathrm{C}$ for $5 \mathrm{~min} ; 35$ cycles of $94{ }^{\circ} \mathrm{C}$ for $1 \mathrm{~min}, 56-62{ }^{\circ} \mathrm{C}$ for $1 \mathrm{~min}, 72{ }^{\circ} \mathrm{C}$ for $1 \mathrm{~min}$; and a final extension step of $72{ }^{\circ} \mathrm{C}$ for $10 \mathrm{~min}$. The products were verified by agarose gel electrophoresis and documented using Quantity One software (Bio-Rad, USA). The band intensity of the resolved cDNA fragments of p53 was normalized with that of the internal control $\beta$-actin and expressed as OD units relative to $\beta$ actin. All of the experiments were performed in two batches and subjected to the individual Student's ' $t$ ' test to assess the variation $p<0.05$ level.

\subsection{DNA fragmentation assay}

To investigate the internucleosomal DNA fragmentation caused by pcAgNPs, a DNA fragmentation assay was performed according to the standard procedure described by Collins et al. (1997) with slight modifications. ${ }^{33}$ A total of $1 \times 10^{5}$ cells were treated with pcAgNPs $\left(15 \mu \mathrm{g} \mathrm{mL}^{-1}\right)$ for $24 \mathrm{~h}$ and then collected by centrifugation. Furthermore, the DNA was isolated using a commercially available kit (Genei, Bangalore, India) following the manufacturer's instructions. The DNA was resolved on a $1.5 \%$ agarose gel $\left(0.5 \mu \mathrm{g} \mathrm{mL}{ }^{-1}\right.$ ethidium bromide in the $1 \times$ TAE buffer, $\mathrm{pH} 8.5$ ) at $100 \mathrm{meV}$ for $90 \mathrm{~min}$ and the bands were visualized using a UV transilluminator.

\subsection{Western blotting}

First, $1 \times 10^{5}$ cells exposed to pcAgNPs were washed twice with ice-cold $1 \times$ PBS solution and centrifuged at $5000 \mathrm{rpm}$ for $5 \mathrm{~min}$. The pellet was lysed in a RIPA buffer containing $150 \mathrm{mM} \mathrm{NaCl}$, Triton $\mathrm{X}-100,50 \mathrm{mM}$ Tris- $\mathrm{HCl}(\mathrm{pH}$ 8), 0.5\% sodium deoxycholate, $0.1 \%$ SDS, and protease and phosphatase inhibitors. The protein lysates $(20 \mu \mathrm{g})$ were subjected to protein electrophoresis on $10 \%$ NuPAGE ${ }^{\circledR}$ Bis-Tris gels (cat. no. NP0301BOX, ThermoFisher Scientific, CA) according to the manufacturer's instructions. Then, the gels were blotted onto a nitrocellulose membrane (cat. no. 162-0113, Bio-Rad, Italy) for $2 \mathrm{~h}$ in Tris-glycine buffer. The membranes were blocked in a PBS $0.1 \%$ Tween 20 solution containing $3 \%$ of BSA, probed with specific antibodies and developed using the ECL Blotting Substrate (cat. no. K-12045-C20, Advansta, USA).

In the western blotting analysis, the following primary antibodies were used: rabbit polyclonal anti-p21 (1:100) (cat. no. TA322940, OriGene, USA), mouse monoclonal anti-p53 (1 : 500) (cat. no. TA327920, OriGene, USA), and mouse monoclonal anticatalase $(1: 100)$ (cat. no. TA502496, OriGene, USA). Mouse monoclonal anti- $\beta$-actin $(1: 10$ 000) (cat. no. TA355041, OriGene, USA) was used to control loading and to purify the peroxidase-conjugated affinity goat anti-mouse IgG (cat. no. TA130003, OriGene, USA). The primary and secondary antibodies used were diluted in a PBS-0.1\% Tween 20 solution containing $3 \%$ of BSA (cat. no. P3563, Sigma-Aldrich, USA).

\subsection{Densitometric analysis}

Protein bands were quantified by densitometric analysis using the Image J software (http://imagej.nih.gov).

\subsection{Statistical analysis}

Experiments conducted in the present study on the antibiogram pattern, measurement of the zone of inhibition, and bactericidal and anti-proliferative activities were performed in triplicate. The results of the experiments were interpreted using ORIGIN 8.0 and expressed as the mean \pm SD (standard deviation) of the concentration of AgNPs. The Student's $t$-test was used to demonstrate the statistical significance. The difference was considered to be statistically significant when the $p$-value was at least $<0.05$.

\section{Results and discussion}

\subsection{Identification of potential strain}

In this study, NPs were synthesized successfully using a rhizosphere-inhabiting environmental isolate Pseudomonas aeruginosa isolated from soil samples collected from paddy fields, and it was designated PA6 for laboratory reference. Of the 51 pigmented strains isolated from six different rhizosphere soils (Table 1), around $68.6 \%(n=35)$ were expected to be Pseudomonas aeruginosa, which were identified based on the biochemical characteristics such as non-lactose fermenting property, being oxidase-positive, pigment production and growth at $40{ }^{\circ} \mathrm{C}$. These strains were then individually screened for the production of pyocyanin; sixteen (45\%) of them produced $\leq 4 \mu \mathrm{g} \mathrm{mL} \mathrm{m}^{-1}$, whereas the remaining $55 \%$ showed production in the range of $5.3-6.5 \mu \mathrm{g} \mathrm{mL}{ }^{-1}$. Table 1 reveals that $P$. aeruginos $^{\mathrm{pa} 6}$ isolated from paddy-cultivated soil shows

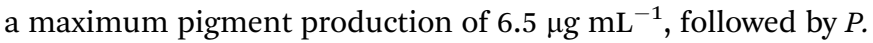

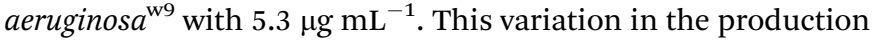
of pyocyanin among the Pseudomonas strains can be attributed to regulators. ${ }^{34}$ The higher pigment producer $P$. aeruginos $a^{\mathrm{pa} 6}$ 
Table 1 Screening of different Pseudomonas aeruginosa from different sources and their pigment production ${ }^{a}$

\begin{tabular}{llll}
\hline Source of isolation & $\begin{array}{l}\text { No. of pigmented } \\
\text { isolates }\end{array}$ & $\begin{array}{l}\text { P. aeruginosa } \\
\text { strains } \text { exp }\end{array}$ & $\begin{array}{l}\text { Pyocyanin production } \\
\left(\mu \mathrm{g} \mathrm{m}^{-1}\right)\end{array}$ \\
\hline Corn-cultivated soil & 5 & 3 & $3.2^{\mathrm{c} 2}$ \\
Paddy-cultivated soil & 13 & 9 & $6.5^{\mathrm{pa}}$ \\
Pulse-cultivated soil & 6 & 4 & $1.9^{\mathrm{pu}}$ \\
Uncultivated soil & 8 & 6 & $3.9^{\mathrm{u} 5}$ \\
Wastewater irrigated soil & 15 & 10 & $5.3^{\mathrm{w} 9}$ \\
Fresh water irrigated soil & 4 & 3 & $2.7^{\mathrm{f3}}$
\end{tabular}

$a$ exp expected $P$. aeruginosa strains based on biochemical characteristics; ${ }^{\mathrm{c} 2, \mathrm{pa6}, \mathrm{pu} 1, \mathrm{u} 5, \mathrm{w} 9, \mathrm{f} 3}$ strains of $P$. aeruginosa isolated from different sites for the production of pyocyanin pigment.

was preferred and its identification was confirmed as a $P$. aeruginosa strain; its 16S rRNA partial gene sequence was submitted to the GenBank and we obtained the accession no. KM216846.1.

\subsection{Optimization studies on the pcAgNP synthesis}

P. aeruginosa ${ }^{\mathrm{pa} 6}$ exhibited higher pigment production, as evidenced by the change in colour to bluish green and through spectrophotometric analysis. The absorbance maxima $\left(\lambda_{\max }\right)$ at $\sim 278 \mathrm{~nm}$ (Fig. 1) revealed the characteristic pyocyanin pigment with bluish green color, which was retained for the synthesis of silver nanoparticles. ${ }^{21,22}$ A significant change in color (yellowish brown) of the reaction mixture was observed after a thorough examination by varying the physicochemical parameters. The absorbance maxima $\left(\lambda_{\max }\right)$ and surface plasmon resonance remained the same, showing a characteristic peak at $420 \mathrm{~nm}$, which confirmed the bio-reduction of silver. It was determined from the spectrophotometric analysis that the yield of AgNPs

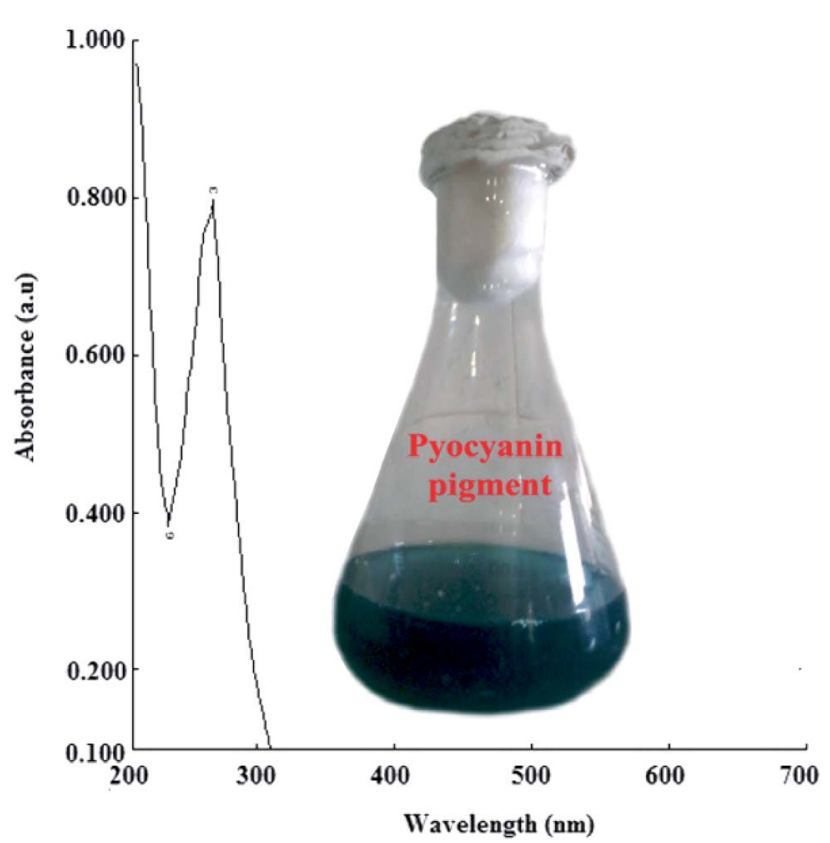

Fig. 1 UV-visible spectroscopic analysis of bluish green pigment (inset) produced by $P$. aeruginosa ${ }^{\mathrm{pa} 6}$. was found to be maximum at a temperature of $37 \pm 2{ }^{\circ} \mathrm{C}$ and neutral $\mathrm{pH}(7.0)$ with a concentration of $1 \mathrm{mM}$ in a $72 \mathrm{~h}$ reaction period. The yield of silver nanoparticles obtained was quantified to be $0.035 \mathrm{mg} / 100 \mathrm{~mL}$.

\subsection{Characterization of pcAgNPs}

The diffusible bluish-green pigment produced by $P$. aerugino$s a^{\mathrm{pa} 6}$ was used as a reducing and stabilizing agent in the synthesis protocol. A change in color to yellowish brown indicated the formation of silver nanoparticles. The spectra of pcAgNPs were analyzed periodically using the supernatant obtained by centrifuging the reaction mixture at $8000 \mathrm{rpm}$ for $20 \mathrm{~min}$. The absorption spectra of the silver nanoparticles showed a strong single peak with a maximum at $\sim 420 \mathrm{~nm}$ (Fig. 2) with an increase in the reaction time $(72 \mathrm{~h})$ and a maximum yield. ${ }^{35}$ This is in agreement with the results of a biological method of nanoparticle synthesis. ${ }^{25,36}$

The XRD analysis of the bio-synthesized pcAgNPs (Fig. 3) revealed the face-centered cubic (fcc) symmetry and crystal structure of silver (nanocrystals). Prominent peaks at respective $2 \theta=38.02^{\circ}, 44.24^{\circ}, 64.35^{\circ}$, and $77.28^{\circ}$ representing zero-valent fcc silver indexed for the (1 111 ), ( $\left.\begin{array}{lll}2 & 0 & 0\end{array}\right),\left(\begin{array}{lll}2 & 2 & 0\end{array}\right)$, and (3 111 ) crystal planes, respectively, due to Bragg's reflections were present (JCPDS file no. 04-0783) ${ }^{37}$ in addition to other peaks, which could have resulted due to the biomolecular interactions with nanoparticles.

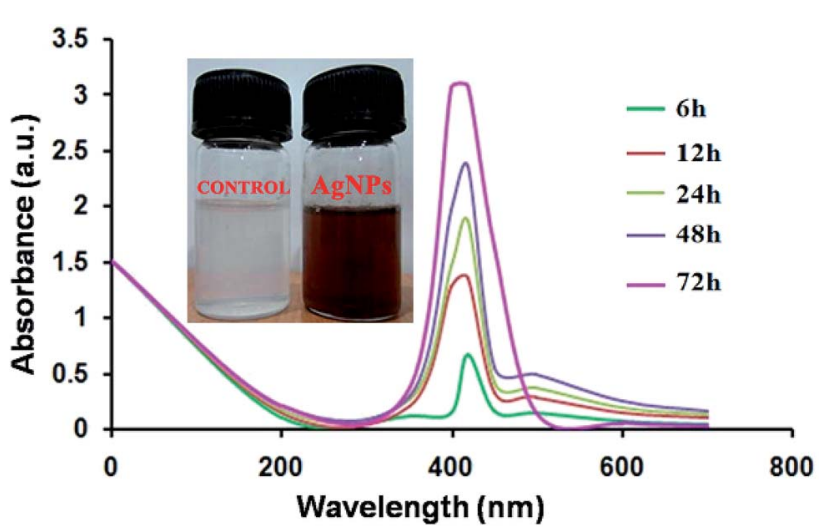

Fig. 2 UV-visible spectrophotometric analysis of pigment-capped AgNPs (pcAgNPs) at different time intervals. 


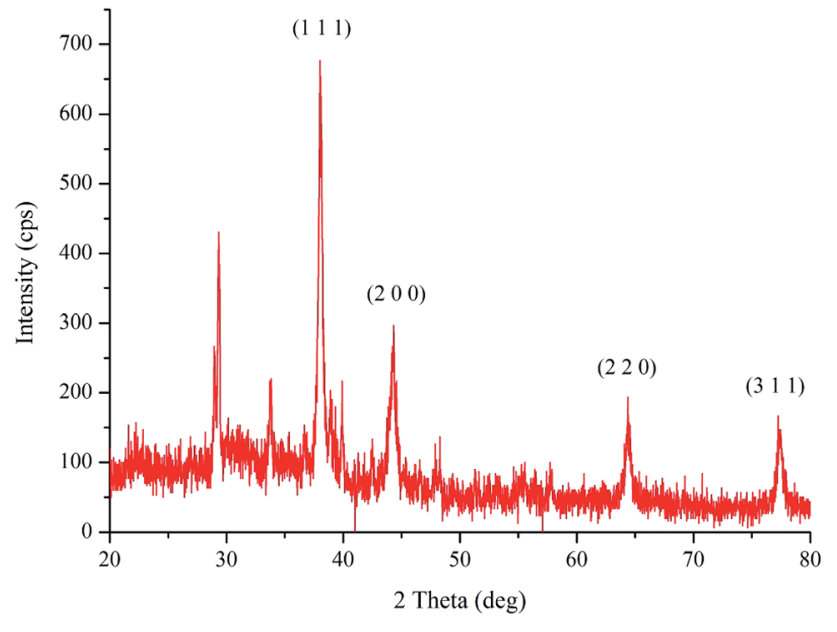

Fig. 3 X-ray diffraction pattern of the biosynthesized pcAgNPs.

The topography and size of pcAgNPs were examined by atomic force microscopy (AFM), dynamic light scattering (DLS) and high-resolution transmission electron microscopy (HRTEM). As observed from the atomic microscopy results, the topography of the silver nanoparticles with no definite agglomeration confirms the polydispersity of the nanoparticles
(Fig. 4A). Subsequently, the particle size distribution of the silver nanoparticles (Fig. 4B) unveiled the narrow size distribution in the range of $25-55 \mathrm{~nm}$, with the mean diameter of $40 \mathrm{~nm}$ and zeta potential of $-32.3 \mathrm{mV}$; this indicated a strong electrostatic attraction between the silver ions and the metabolites, conferring stability. ${ }^{23,38}$

Further confirmation of the size of the nanoparticles analyzed through HRTEM with SAED patterns (Fig. 4C and D) demonstrated the spherical and nearly spherical shapes of the silver nanoparticles in the size range 25-50 $\mathrm{nm}$, which were found to be consistent with the results obtained from dynamic light scattering. The inset of Fig. 4D shows the selected area diffraction (SAED) pattern of the silver nanoparticles. The smooth surface and ring-like diffraction pattern indicate that the particles are crystalline with the characteristic lattice planes of silver. ${ }^{39}$

FT-IR spectroscopy was performed to analyze the functional quality of the product and the spectrum was acquired in the range of $4000-400 \mathrm{~cm}^{-1}$ (Fig. 5). The band seen at $3400.9 \mathrm{~cm}^{-1}$ is assigned to the stretching vibrations of $\mathrm{O}-\mathrm{H}$ and $\mathrm{H}$. The bending vibration of primary amine can be observed in the region of $1650-1580 \mathrm{~cm}^{-1}$ and the $\mathrm{C}-\mathrm{N}$ stretching vibrations correspond to aliphatic amines, as represented by a peak in the region of $1250-1020 \mathrm{~cm}^{-1}$. This indicated the involvement of
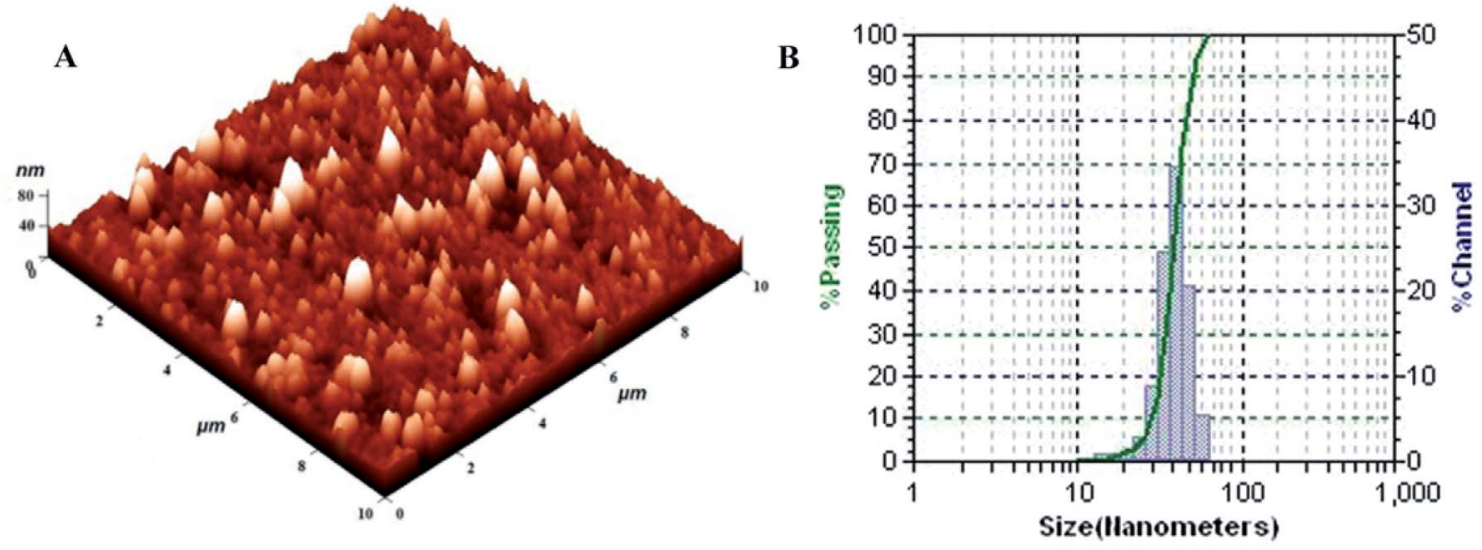

C

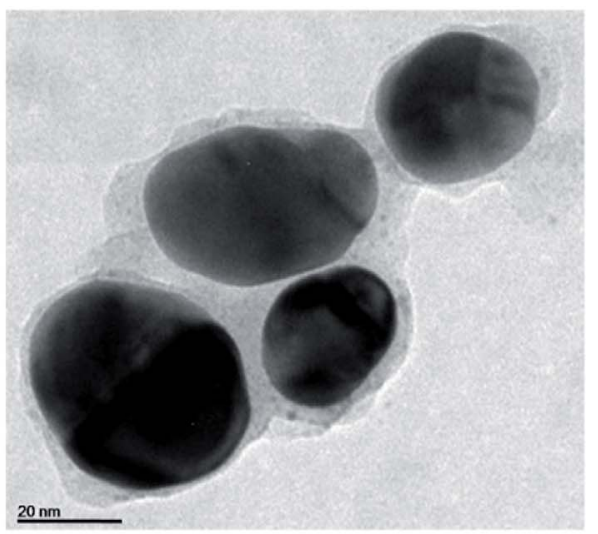

D

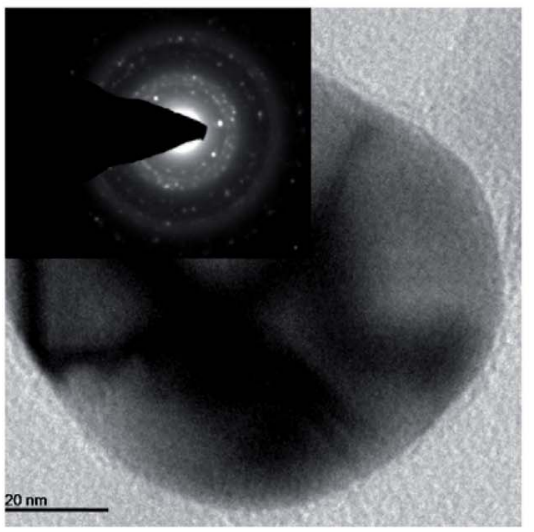

Fig. 4 Characterization of pcAgNPs. Atomic Force Microscopic image of size $10 \times 10 \mu \mathrm{m}$ with height profile at $80 \mathrm{~nm}$ (A); hydrodynamic diameter in the range of 10-100 nm (B); HR-TEM micrograph at a scale bar of $20 \mathrm{~nm}(\mathrm{C})$; and the corresponding SAED pattern showing four diffraction rings, indicating the purity at a scale bar of $20 \mathrm{~nm}$ (D). 


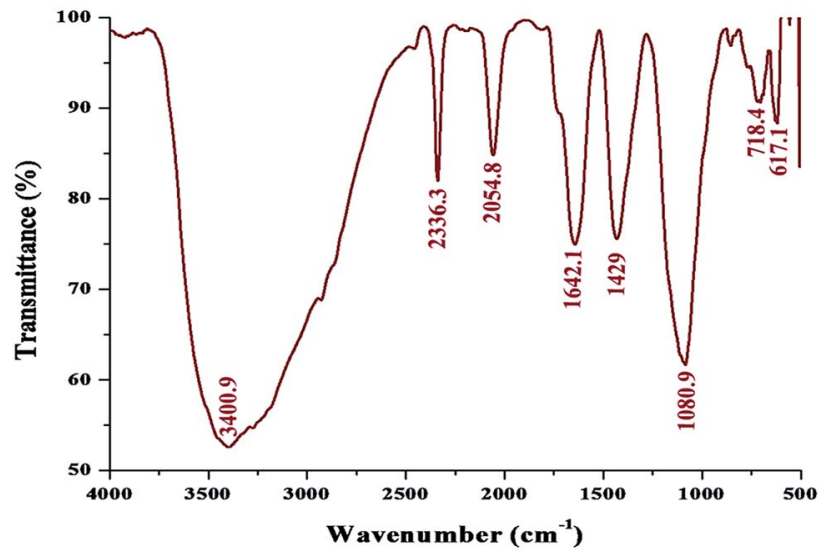

Fig. 5 FT-IR spectrum of the biosynthesized pcAgNPs showing the possible biomolecular interactions of the pigment.

a polypeptide, as evidenced from the amide linkages between the amino acid residues. In addition, the stretching vibrations of -C-C- were observed at $1429 \mathrm{~cm}^{-1}$, which accounted for the aromatic compound involved in the reaction; this is probably the role of pyocyanin (pigment), offering stability to the nanoparticles. From the observation, it was confirmed that biomolecules such as protein and pigment moieties were involved in the reduction and stabilization of silver nanoparticles through intermolecular attractions. ${ }^{\mathbf{4 0 , 4 1}}$

\subsection{Antimicrobial activity}

The antimicrobial study using nanomaterials was performed because of the increase in the multidrug-resistant strains of bacteria, which could provide insights for an alternative drug of choice including AgNPs and silver-based products. pcAgNPs prepared at various concentrations were found to be effective toward a series of antibiotic-resistant bacterial strains on par with those exposed to broad-spectrum antibiotics such as Amikacin, Tetracycline, Vancomycin, Cefepime, Netilmicin, Doxycycline and Chloramphenicol (Table 2) at $25 \mu \mathrm{g} \mathrm{mL}{ }^{-1}$. The antibiogram pattern of the clinical isolates showed complete resistance toward a series of antibiotics at $25 \mu \mathrm{g} \mathrm{mL} \mathrm{m}^{-1}$ as compared with the standard antibiotic susceptibility chart.

AgNPs $\left(5,15,25\right.$ and $50 \mu \mathrm{g} \mathrm{mL} \mathrm{m}^{-1}$ ) exhibited significant antimicrobial activity toward all antibiotic-resistant Grampositive and Gram-negative strains in a dose-dependent manner. Proteus mirabilis showed maximum susceptibility toward pcAgNPs with $\sim 25 \mathrm{~mm} \mathrm{ZOI}$, followed by $K$. pneumoniae $(24 \mathrm{~mm})$ and Acinetobacter baumannii $(24 \mathrm{~mm})$. The isolates that did not respond to the broad-spectrum antibiotics such as MRSA and MRSE showed susceptibility toward pcAgNPs at the same concentration as that of the antibiotics. A similar trend was observed in the case of $E$. coli and the vancomycin-resistant Enterococcus sp. with a $\sim 22 \mathrm{~mm}$ inhibition zone.

Furthermore, to manifest the antibacterial effect induced by pcAgNPs, the FESEM technique was adopted, for which Enterococcus sp. (VRE) and E. coli models were used. Regular FESEM micrographs (Fig. 6) revealed significant membrane damage on both the strains exposed to $25 \mu \mathrm{g} \mathrm{mL} \mathrm{m}^{-1}$ of pcAgNPs in $6 \mathrm{~h}$ from their exposure (Fig. 6b and d), whereas the control cells sustained no such damage and retained the coccal and rod-shaped morphologies (Fig. 6a and c). It was assumed that the dissolved silver ions' interaction with the trans-membrane proteins leads to the release of $\mathrm{H}^{+}$by the influence of the proton-motive force, ${ }^{42}$ resulting in the formation of 'pits' that damage the cell walls. ${ }^{43}$ Subsequently, the membrane components became disorganized from their intact nature, accounting for the structural changes in the cell walls. This disrupted the permeability, which led to the death of the cells. The antimicrobial susceptibility toward the Gram-negative bacterium sustained extensive structural damage than the observation for the Gram-positive bacterium. It was presumed that the presence of the thick peptidoglycan in the Gram-positive bacterium has the ability to trap the positively charged silver ions. These phenomena suggest a possible antibacterial mechanism exerted by pcAgNPs through membrane damage and inhibition of cellular response. ${ }^{\mathbf{4 4}}$

\subsection{Mechanistic antibacterial effect}

It was evident from the electron microscopic study that pcAgNPs adhere and pass through the plasma membrane, creating pits that result in bacterial cell death. Reports on the metal-microbe interaction induced a significant rise in ROS, bringing about a deleterious effect related to oxidative stress. ${ }^{45}$ Therefore, the oxidative stress in the Gram-positive Enterococci (VRE) and Gramnegative $E$. coli after treatment with pcAgNPs was determined through the measurement of intracellular ROS generated using the DCFH-DA assay. This oxidation-sensitive fluorescent probe diffuses passively through the cell membrane and gets deacetylated by esterase to form non-fluorescent DCFH. When it comes in contact with ROS, it reacts to form a fluorescent product DC trapped inside the cell. Thus, the ROS level was directly proportional with the fluorescence intensity at $510 \mathrm{~nm}$ and in turn was correlated with the antibacterial effect of pcAgNPs on the bacterial cells. Fig. 7c clearly reveals the ROS generation with increased concentrations of pcAgNPs. The control cells (untreated with pcAgNPs) showed no difference; however, as the concentration of pcAgNPs increased, there was increased ROS generation (75-85\%) at $50 \mu \mathrm{g} \mathrm{mL} \mathrm{m}^{-1}$ as compared with that for the positive control (100\%), pertaining to the ROS-mediated cell death. ${ }^{46}$

Furthermore, to guarantee the state of the organisms that succumbed to cell death, the intracellular glutathione (GSH) concentration was measured. Glutathione, the most potent natural antioxidant, influences the physiological and biochemical aspects of both prokaryotic and eukaryotic cells. Eukaryotic cells possess relatively higher concentrations of GSH than prokaryotes, but it is chiefly found in E. coli, Streptococcus and Enterococcus sp. to maintain the cellular redox environment and protect the cells against oxidative stress by scavenging ROS. This tripeptide is present in the cytosol of cells at a concentration of 1-2 mM GSH. When this reduced form of GSH comes in contact with free radicals, it results in the formation of GS* (thiyl radical), which then reacts with another GS* radical to form glutathione disulphide (GSSG), an important regulator of biological processes. ${ }^{47}$ 
Table 2 Antimicrobial susceptibility testing of various concentrations of pcAgNPs and $1 \mathrm{mM} \mathrm{AgNO}$ toward a series of clinical isolates of bacteria after $24 \mathrm{~h}$ of treatment ${ }^{a}$

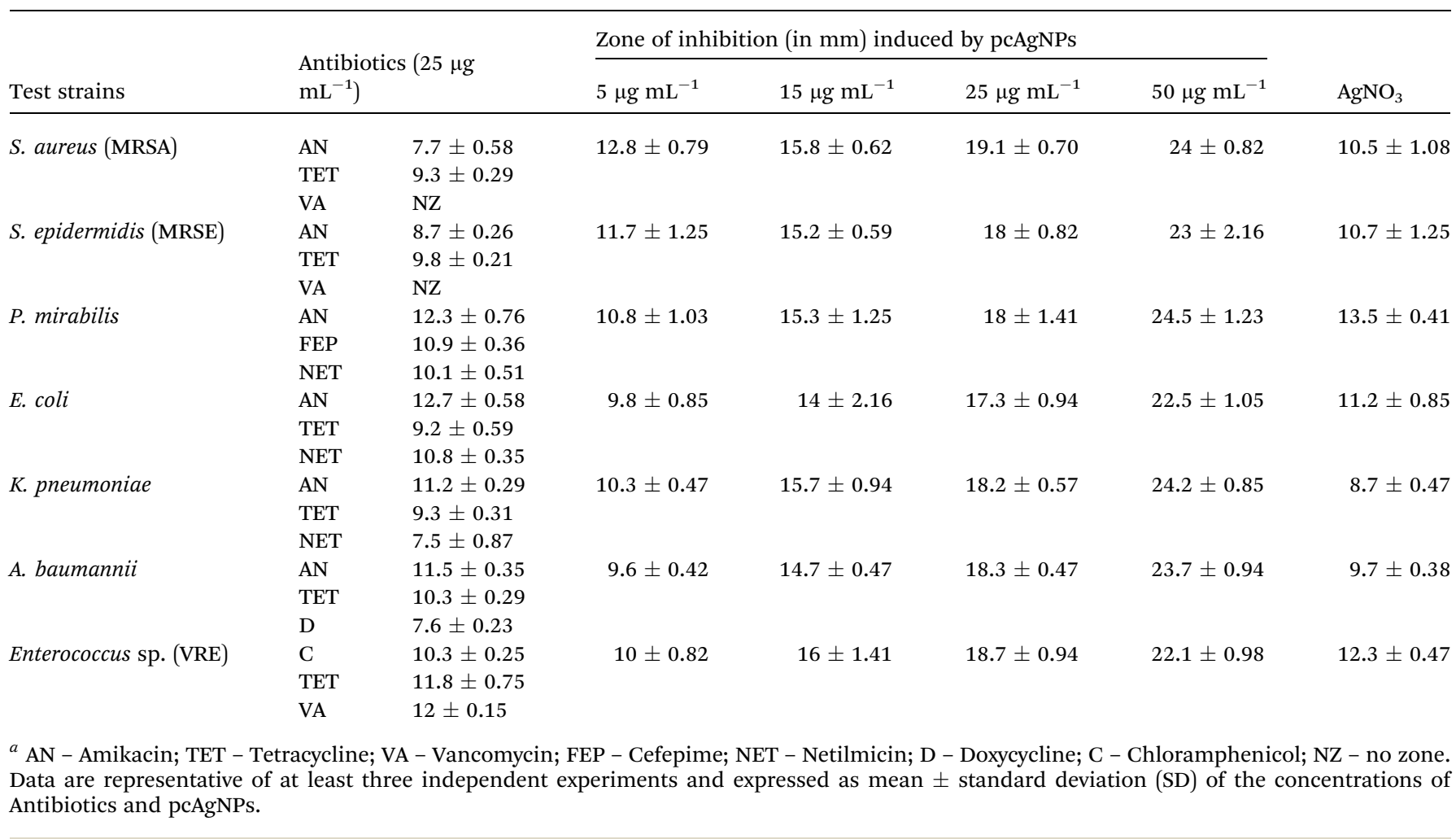

To decipher the oxidative stress induced by pcAgNPs, the intracellular GSH concentration was measured in pcAgNPtreated cells. As discussed, the initial concentrations of GSH were found to be $1.54 \pm 0.41$ and $1.26 \pm 0.32$, respectively, for the Enterococcus sp. and E. coli (control) cells (Fig. 7a). Besides, the pcAgNP-treated cells showed sequential depletion of GSH
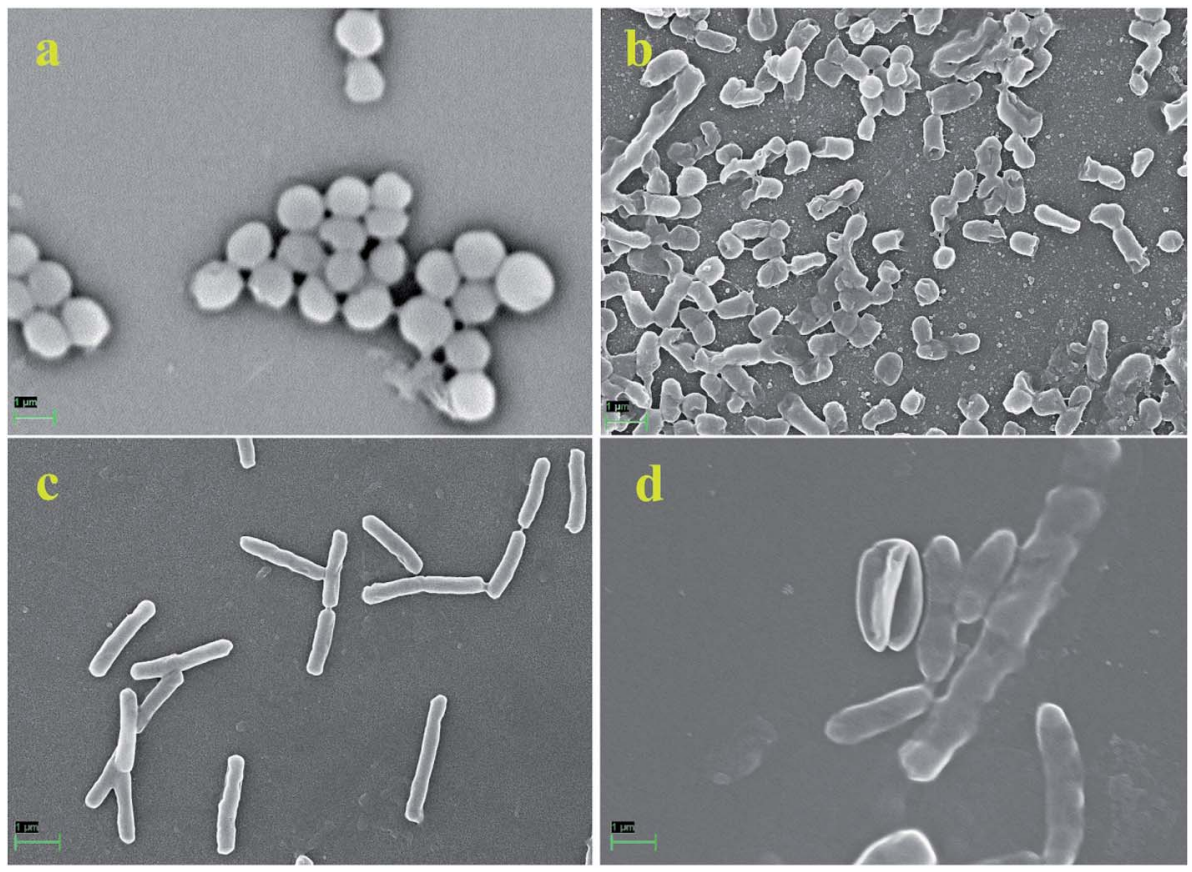

Fig. 6 FESEM micrographs of antimicrobial susceptibility testing of pcAgNPs at $25 \mu \mathrm{g} \mathrm{mL}^{-1}$ toward Gram-positive and Gram-negative strains at a scale bar of $1 \mu \mathrm{m}$ observed after $24 \mathrm{~h}$ of treatment with typical membrane damage. Enterococcus sp. (VRE) control (a); Enterococcus sp. (VRE) treated with pcAgNPs showing cell damage (b); E. coli control (c) and E. coli treated with pcAgNPs (d). 
(a)

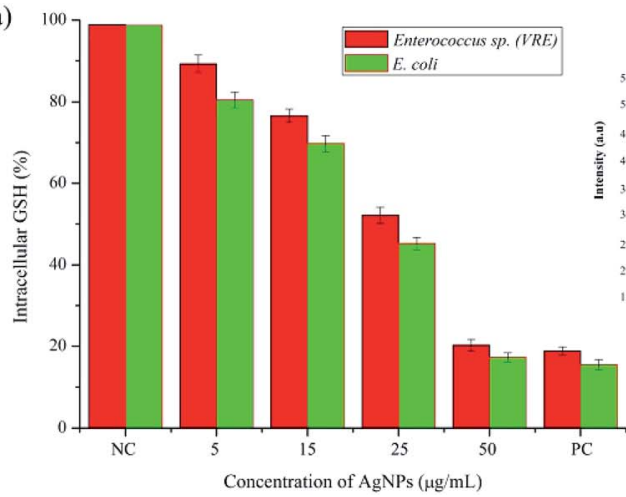

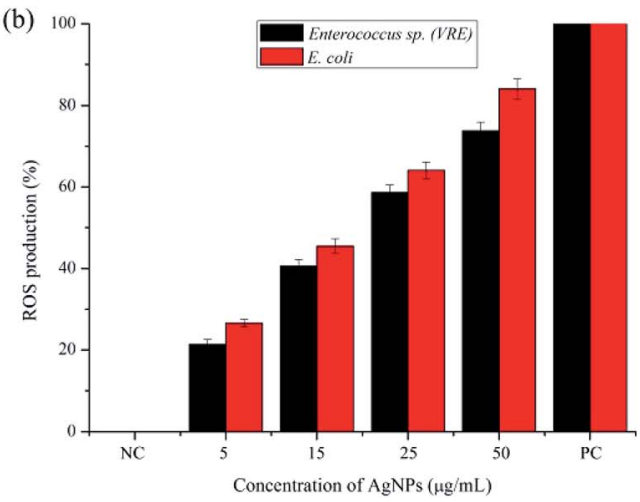

Fig. 7 Effect of pcAgNPs on the intracellular GSH concentration (a); DCFH-DA assay (b) for the quantification of ROS generation and the level of ROS production in pcAgNP-treated cells (c).

with a subsequent increase in the concentration. At $25 \mu \mathrm{g} \mathrm{mL} \mathrm{L}^{-1}$ concentration, there was three-fold reduction in the concentration of GSH to $0.54 \pm 0.14$ and $0.41 \pm 0.06 \mathrm{mM}$, respectively, for Enterococci sp. and E. coli. Furthermore, the cells treated with $50 \mu \mathrm{g} \mathrm{mL}{ }^{-1}$ pcAgNPs showed steady decline in the GSH concentration, i.e., $\leq 0.2 \mathrm{mM}$, which was negligible enough to support and protect the cells from cessation. The results from these studies suggested that the oxidative damage caused by ROS associated with reduced glutathione concentration might be responsible for the antibacterial activity of pcAgNPs. ${ }^{48}$

\subsection{In vitro antiproliferative effect of pcAgNPs}

3.6.1. Cytotoxic effect of pcAgNPs on HEp-2 cells. Cell viability bioassays serve as the basic steps for toxicological studies in explaining the cellular response to a toxicant, providing information on cell death, survival, and metabolic processes. The cytotoxicity of the synthesized pcAgNPs in the Vero and HEp- 2 cells was evaluated using MTT assays. There was a significant cytotoxic effect induced by pcAgNPs in a dosedependent manner $(0.7,1.5,3.1,6.2,12.5,25,50$ and $100 \mu \mathrm{g}$ $\left.\mathrm{mL}^{-1}\right)$. Total cell death, i.e., 100\% mortality was observed at higher concentrations and the half maximal inhibitory concentration $\left(\mathrm{IC}_{50}\right.$ ) values were fixed at $7.38 \mu \mathrm{g} \mathrm{mL}{ }^{-1}$ and 14.8 $\mu \mathrm{g} \mathrm{mL}{ }^{-1}$, respectively, for the Vero and HEp-2 cells (Fig. 8). This was further confirmed by the change in morphology associated with cell rounding, reduction in cell size and detachment from the substratum (Fig. 9b and d). In contrast, the control showed a confluent monolayer (Fig. 9a and c), as evident from the phase contrast microscopic observation and viable cell staining (Fig. 9i-iv). This difference in cytotoxicities induced by pcAgNPs varied with the type and source of mammalian cells in vitro, ${ }^{49,50}$ relying upon the time of exposure and surface properties.

3.6.2. Induction of apoptosis by pcAgNPs. AO/EB staining was performed to study whether the inhibitory effect of pcAgNPs on HEp-2 cells was due to apoptosis. The stained adherent cells showed morphological changes associated with the cell shape and chromatin condensation, which is one of the key factors in inducing apoptosis. The stained cells were differentiated into viable (green) (Fig. 10a), early apoptotic (condensed chromatin and green fluorescence) (Fig. 10b), and late apoptotic (orange fluorescence) (Fig. 10c). The apoptotic features such as cell contraction, nuclear condensation, shredding, membrane blebbing and formation of apoptotic bodies were observed in pcAgNP-treated cells using DAPI, whereas the cells in the control group were confluent, regular and with complete morphological characteristics (Fig. 10d, e and $\mathrm{f}) .{ }^{51}$

3.6.3. Interaction of pcAgNPs with DNA. A DNA fragmentation assay was performed to evaluate the DNA damage in the pcAgNP-treated HEp-2 cells. As shown in Fig. 11a, the DNA strand breaks in fragments at $14.8 \mu \mathrm{g} \mathrm{mL}$; this clearly indicates that pcAgNPs can preferentially interact with the nucleotide bases, leading to multi-site cleavage and DNA damage. ${ }^{42}$ In contrast, the untreated cells show a clear distinct band. The strong affinity between pcAgNPs and DNA is known to act as an important mediator that can induce apoptosis. The present study is in line with the earlier reports on the mechanism of AgNP toxicity involving the mitochondrial respiratory chain disruption, induction of ROS and interruption of ATP synthesis, thereby damaging DNA. ${ }^{52}$

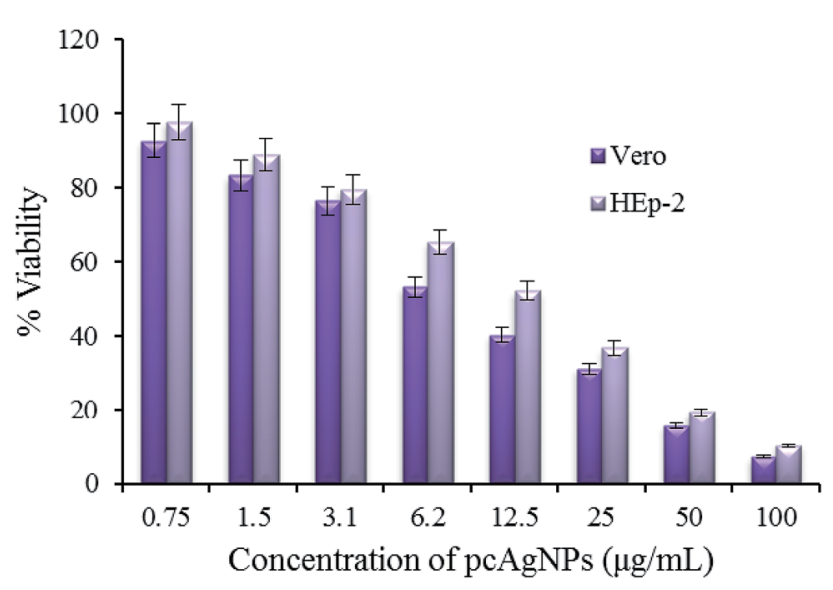

Fig. 8 Cytotoxicity of Vero and HEp-2 cells exposed to pcAgNPs and their corresponding $I C_{50}$ values. The $I C_{50}$ value of Vero cells was $7.8 \mu \mathrm{g}$ $\mathrm{mL}^{-1}$ and that of HEp-2 cells was $14.3 \mu \mathrm{g} \mathrm{mL}^{-1}$. 


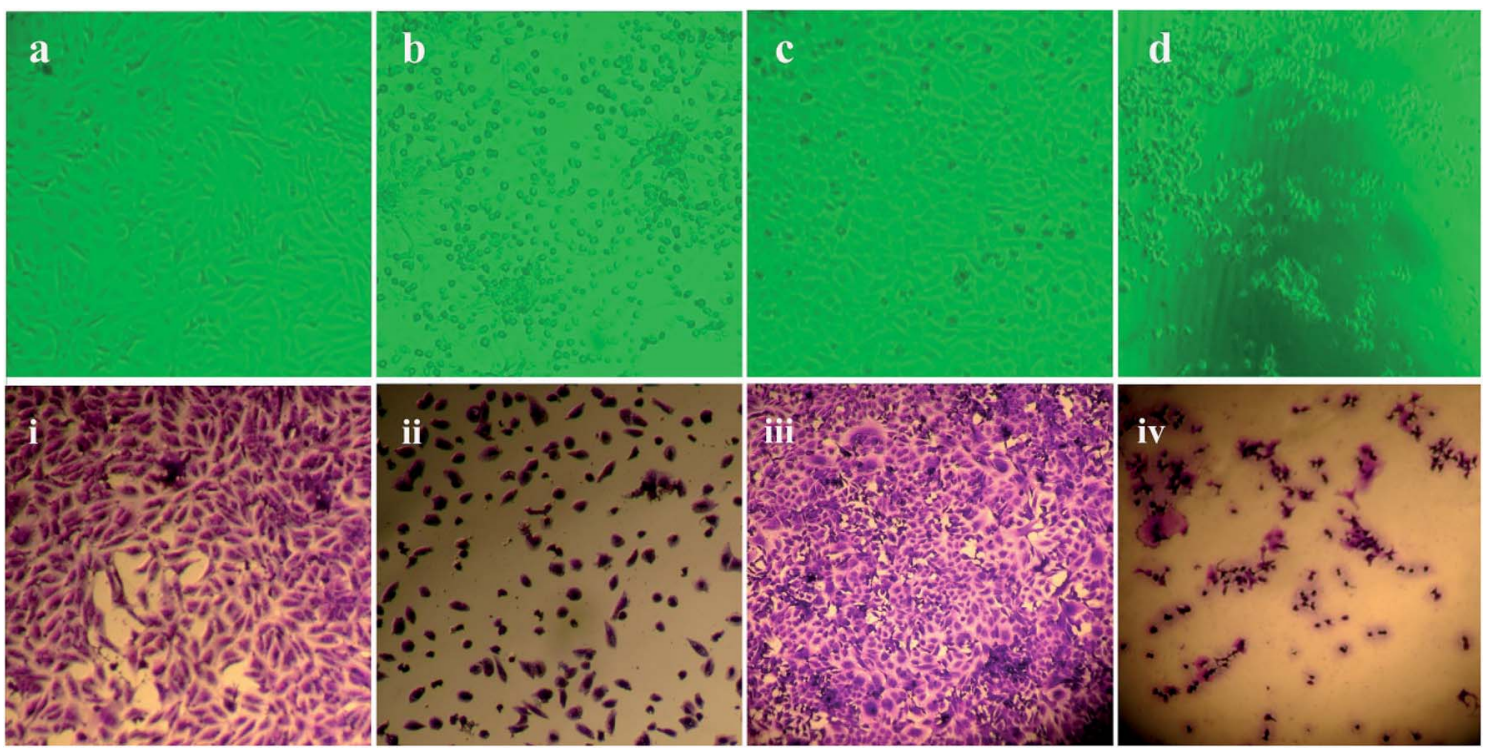

Fig. 9 Phase contrast microscopic images of Vero and HEp-2 cells exposed to pcAgNPs and their corresponding cells stained with crystal violet observed with a $10 \times$ objective. Vero control ( $a$ and i); Vero cells at $I_{50}$ concentration (b and ii); HEp-2 control (c and iii); HEp-2 cells at IC 50 concentration (d and iv).

3.6.4. Apoptotic pathway. The possible molecular mechanisms of pcAgNP-mediated apoptotic cell death through the mRNA expression patterns of the p53 gene were measured by RT-PCR. The target gene expression was normalized with the levels of the $\beta$-actin expression (Fig. 11b and c). The RT-PCR result revealed significant upregulation of the p53 gene expression on HEp-2 cells treated with pcAgNPs, suggesting the involvement of the mitochondrial pathway in the induction of apoptosis. ${ }^{53}$

The apoptotic regulation mainly depends upon the transcriptional regulation of the target gene(s), possibly reflecting the mechanism of the p53 action in different cell types. Although p53 encodes a nuclear phosphoprotein with cancerinhibiting properties, most of them remain inactive in more than half of human cancers. ${ }^{54}$ There is compelling evidence of protein accumulation in the mitochondria in response to abnormal proliferative signals and oxidative stress including DNA damage.

We showed in this study that pcAgNPs induced the expression of p53 as HEp-2 cells possess wild-type p53, which are nonfunctional and normally kept at low levels. The up-regulation of p53 (Fig. 11c and d) occurred in cells exposed to toxicant(s); in this case, pcAgNPs determined the tumor suppression function and apoptosis. ${ }^{55}$ We found that the pcAgNP treatment in HEp-2 cells upregulated the levels of p21 (Fig. 11d), the target of p53, when compared with the observation for control cells. Moreover, we also found that pcAgNPs increased the protein levels of catalase, one of the most important scavenger enzymes reported
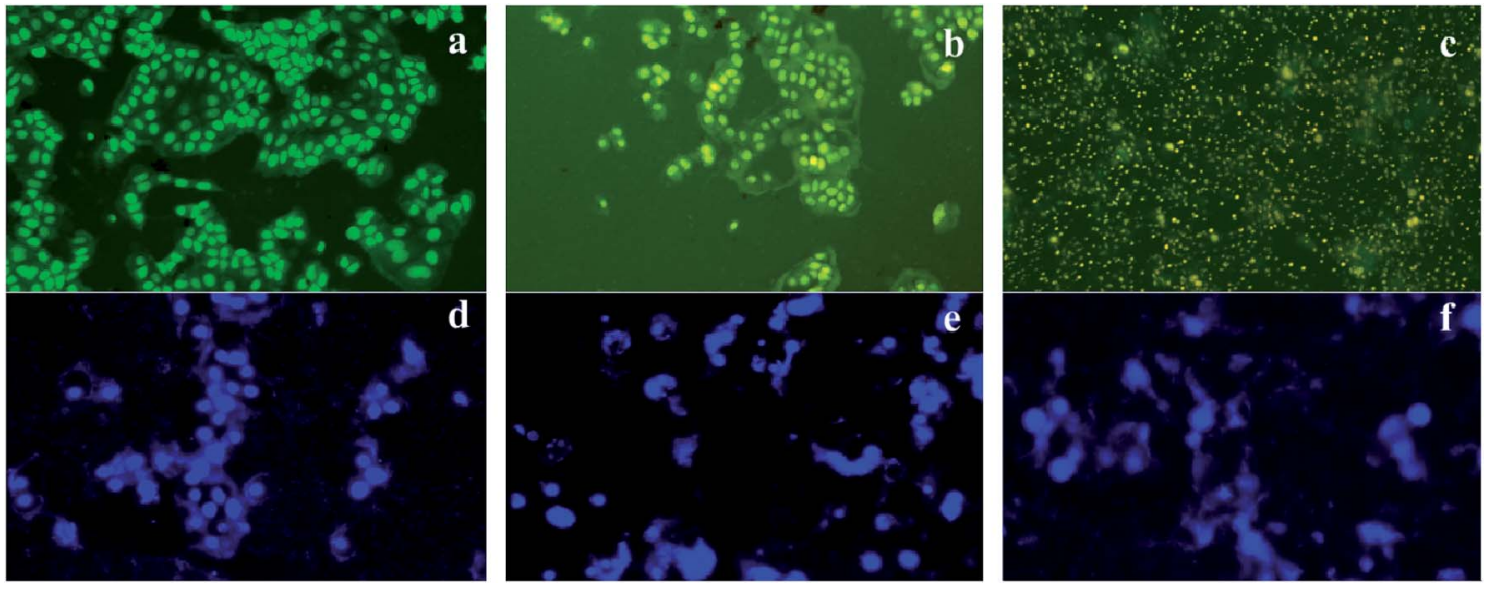

Fig. 10 Fluorescence imaging of AO/EB-stained HEp-2 cells $(a-c)$ and DAPI-stained cells $(d-f)$ exposed to pcAgNPs attributing to apoptotic cell death. Green coloration denotes viable cells (a); early apoptotic cells with green fluorescence (b); and late apoptotic cells (c); control cells with intact nuclei (d); chromatin condensation (e) associated with nuclear fragmentation (f). 
(a)

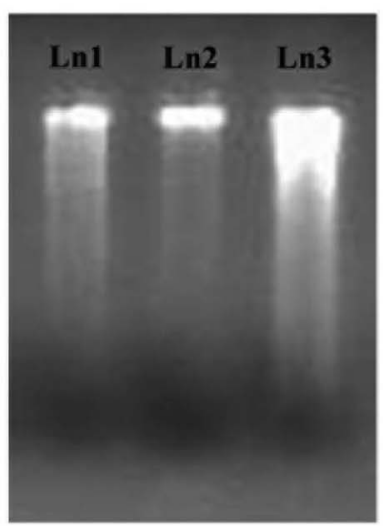

(b)

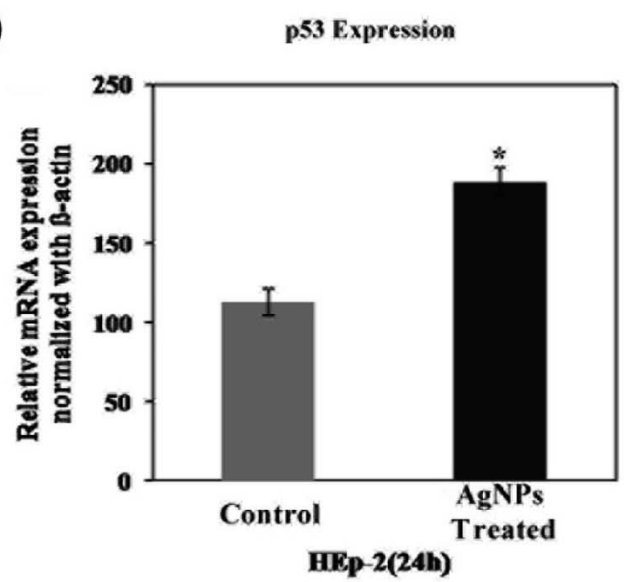

(c)

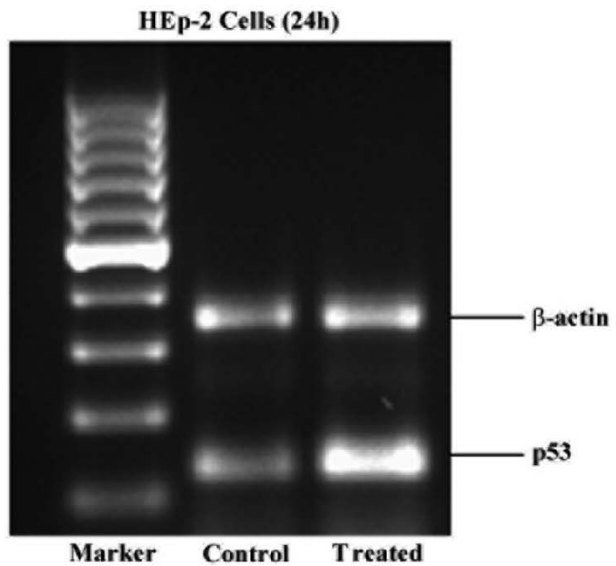

(d)

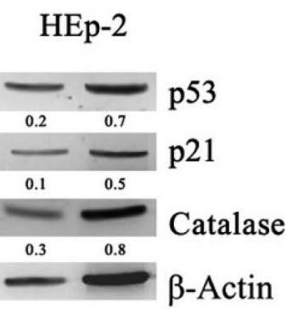

Fig. 11 Apoptotic mechanism of HEp-2 cells treated with pcAgNPs. DNA fragmentation of HEp-2 cells exposed to pcAgNPs (a). RT-PCR analysis of p53 expression, leading to apoptotic cell death ( $b$ and $c$ ); pcAgNP activation of p53, leading to increased catalase expression. HEp-2 cells treated with $15 \mu \mathrm{g} \mathrm{mL}^{-1}$ pcAgNPs for $24 \mathrm{~h}$, showing p53, p21 and catalase expressions assessed using Western blotting analysis. $\beta$-actin served as a loading control. Numbers were calculated by quantitative densitometric analysis and indicate the ratio of specific proteins versus $\beta$-actin. (d) Data are representative of at least three independent experiments.

to be activated by p53. Altogether, these results indicate that pcAgNPs activated p53 to induce HEp-2 cell death possibly through the reduction of the intracellular ROS production by catalase. $^{56}$

Although multiple genes are involved in carcinogenesis, p53 is the most widely studied tumor suppressor gene as most of the wild type-carrying p53 cancer cells need re-activation of its oncosuppressor function. These findings of the pigmentcapped AgNPs from $P$. aeruginosa could provide an insight into gene therapeutic approaches applicable to a wide range of carcinomas. The growing body of research in the area of cancers may bring out a number of possible mechanisms by which p53 regulates tumours and may provide excellent prospects in clinical applications in optimizing targeting strategies.

\section{Conclusion}

We demonstrated the synthesis of silver nanoparticles using a rhizosphere-inhabiting, stress-tolerant $P$. aeruginos $a^{\mathrm{pa} 6}$ and its antimicrobial and anti-proliferative potentials were investigated. The pigment-capped AgNPs showed significant antibacterial activity toward drug-resistant bacteria in a dosedependent fashion on par with standard antibiotics. The study revealed the possible mechanism by which p53 regulates the cell cycle through apoptosis, thus providing a guide for further optimization of a promising gene therapy system.

\section{Conflicts of interest}

There are no conflicts to declare.

\section{Acknowledgements}

The authors greatly acknowledge CSIR-CLRI and Sathyabama Institute of Science and Technology (Deemed to be University) for funding and providing the infrastructural facility.

\section{References}

1 D. K. Eric, Engines of Creation: The Coming Era of Nanotechnology, Doubleday, 1986. 
2 V. Wagner, A. Dullaart, A. K. Bock and A. Zweck, The emerging nanomedicine landscape, Nat. Biotechnol., 2006, 24(10), 1211-1217.

3 D. A. LaVan, T. McGuire and R. Langer, Small-scale systems for in vivo drug delivery, Nat. Biotechnol., 2003, 21(10), 11841191.

4 J. Xu, A. Singh and M. M. Amiji, Redox-responsive targeted gelatin nanoparticles for delivery of combination wt-p53 expressing plasmid DNA and gemcitabine in the treatment of pancreatic cancer, BMC Cancer, 2014, 14, 75 .

5 O. Salata, Applications of nanoparticles in biology and medicine, J. Nanobiotechnol., 2004, 2(1), 3.

6 D. Anderson, Persistence of antibiotic-resistant bacteria, Curr. Opin. Microbiol., 2003, 6(5), 452-456.

7 R. Singh, M. S. Smitha and S. P. Singh, The role of nanotechnology in combating multi-drug resistant bacteria, J. Nanosci. Nanotechnol., 2014, 14(7), 4745-4756.

8 H. R. Kim, Y. Shin da, Y. J. Park, C. W. Park, S. M. Oh and K. H. Chung, Silver nanoparticles induce p53-mediated apoptosis in human bronchial epithelial (BEAS-2B) cells, $J$. Toxicol. Sci., 2014, 39(3), 401-412.

9 P. V. Asharani, G. L. K. Mun, M. P. Hande and S. Valiyaveettil, Cytotoxicity and genotoxicity of silver nanoparticles in human cells, ACS Nano, 2009, 3, 279-290.

10 S. Kim and D. Y. Ryu, Silver nanoparticle-induced oxidative stress, genotoxicity and apoptosis in cultured cells and animal tissues, J. Appl. Toxicol., 2013, 33(2), 78-89.

11 B. Vogelstein, D. Lane and A. J. Levine, Surfing the p53 network, Nature, 2000, 408(6810), 307-310.

12 B. Sharma, W. Ma, I. M. Adjei, J. Panyam, S. Dimitrijevic and V. Labhasetwar, Nanoparticle-mediated p53 gene therapy for tumor inhibition, Drug Delivery Transl. Res., 2011, 1(1), 4352.

13 A. A. Matthew, W. E. Cameron and L. R. Colin, Green chemistry and the health implications of nanoparticles, Green Chem., 2006, 8, 417-432.

14 Q. Wu, H. Cao, Q. Luan, J. Zhang, Z. Wang, J. H. Warner and A. A. R. Watt, Biomolecule-Assisted synthesis of watersoluble silver nanoparticles and their biomedical applications, Inorg. Chem., 2008, 47(13), 5882-5888.

15 S. Su, X. Zuo, D. Pan, H. Pei, L. Wang, C. Fan and W. Huang, Design and applications of gold nanoparticle conjugates by exploiting biomolecule-gold nanoparticle interactions, Nanoscale, 2013, 5(7), 2589-2599.

16 M. Lakshmipathy and A. Nanda, Biocatalysts of silver nanoparticles synthesized using an environmental isolate, Serratia marcescens S01, Int. J. ChemTech Res., 2013, 5(3), 1162-1168.

17 C. Keel, U. Schnider, M. Maurhofer, C. Voisard, J. Laville, U. Burger, P. Wirthner, D. Haas and G. Defago, Suppression of root diseases by Pseudomonas fluorescens CHA0: importance of the bacterial secondary metabolite 2,4-diacetyl phloroglucinol, Mol. Plant-Microbe Interact., 1992, 5(1), 4-13.

18 P. Trivedi, A. Pandey and L. M. Palni, In vitro evaluation of antagonistic properties of Pseudomonas corrugata, Microbiol. Res., 2008, 163(3), 329-336.
19 R. F. Harris and L. E. Sommers, Plate-Dilution frequency technique for assay of Microbial ecology, Appl. Microbiol., 1968, 16(2), 330-334.

20 S. B. Robert, E. G. Murray and R. S. Nathan, Bergey's Manual of Determinative Bacteriology, Baltimore, Williams and Wilkins, 1962, p. 1094.

21 S. Karpagam, T. Sudhakar and M. Lakshmipathy, Microbial response of pyocyanin produced by Ps. aeruginosa toward clinical isolates of fungi, Int. J. Pharm. Pharm. Sci., 2013, 5(3), 870-873.

22 D. W. Essar, L. Eberly, A. Hadero and I. P. Crawford, Identification and characterization of genes for a second anthranilate synthase in Pseudomonas aeruginosa: interchangeability of the two anthranilate synthases and evolutionary implications, J. Bacteriol., 1990, 172, 884-900.

23 A. Nanda and M. Saravanan, Biosynthesis of silver nanoparticles from Staphylococcus aureus and its antimicrobial activity against MRSA and MRSE, Nanomedicine, 2009, 5, 452-456.

24 P. Jeevan, K. Ramya and E. A. Rena, Extracellular biosynthesis of silver nanoparticles by culture supernatant of Pseudomonas aeruginosa, Indian J. Biotechnol., 2012, 11, 72-76.

25 L. Muthukrishnan and A. Nanda, Geno-toxic study of silver bio-nanoparticles toward Gram-positive and Gram-negative clinical isolates, J. Pharma Res., 2013, 6, 725-729.

26 K. Shameli, M. B. Ahmad, S. D. Jazayeri, P. Shabanzadeh, P. Sangpour, H. Jahangirian and Y. Gharayebi, Investigation of antibacterial properties of silver nanoparticles prepared via green method, Chem. Cent. J., 2012, 6, 73.

27 A. W. Bauer, W. M. M. Kirby, J. C. Sherris and M. Turck, Antibiotic susceptibility testing by a standardized single disk method, Am. J. Clin. Pathol., 1966, 36, 493-496.

28 P. Sahoo, P. S. Murthy, S. Dhara, V. P. Venugopalan, A. Das and A. K. Tyagi, Probing the cellular damage in bacteria induced by GaN nanoparticles using confocal laser Raman spectroscopy, J. Nanopart. Res., 2013, 15, 1841.

29 S. H. Kim, L. Hyeong-Seon, R. Deok-Seon, C. Soo-Jae and L. Dong-Seok, Antibacterial activity of silver-nanoparticles against Staphylococcus aureus and Escherichia coli, Korean J. Microbiol. Biotechnol., 2011, 39(1), 77-85.

30 E. J. Park, J. Yi, Y. Kim, K. Choi and K. Park, Silver nanoparticles induce cytotoxicity by a Trojan-horse type mechanism, Toxicol. in Vitro, 2010, 24, 872-878.

31 T. Mosmann, Rapid colorimetric assay for cellular growth and survival: application to proliferation and cytotoxicity assays, J. Immunol. Methods, 1983, 65(1-2), 55-63.

32 Z. Darzynkiewicz, X. Li and J. Gong, Assays of cell viability: discrimination of cells dying by apoptosis, Methods Cell Biol., 1994, 41, 15-38.

33 J. A. Collins, C. A. Schandi, K. K. Young, J. Vesely and M. C. Willingham, Major DNA fragmentation is a late event in apoptosis, J. Histochem. Cytochem., 1997, 45(7), 923-934.

34 H. Liang, J. Duan, C. D. Sibley, M. G. Surette and K. Duan, Identification of mutants with altered phenazine 
production in Pseudomonas aeruginosa, J. Med. Microbiol., 2011, 60, 22-34.

35 M. Lakshmipathy and A. Nanda, Bio-processing and prophylactic efficacy of silver nanoparticles, Proc. Indian Natl. Sci. Acad., 2013, 79(3), 473-479.

36 N. Duran, P. D. Marcato, O. L. Alves, G. I. H. De Souza and E. Esposito, Mechanistic aspects of biosynthesis of silver nanoparticles by several Fusarium oxysporum strains, $J$. Nanobiotechnol., 2005, 3, 8.

37 V. Gopinath, D. MubarakAli, S. Priyadarshini, N. M. Priyadharsshini, N. Thajuddin and P. Velusamy, Biosynthesis of silver nanoparticles from Tribulus terrestris and its antimicrobial activity: a novel biological approach, Colloids Surf., B, 2012, 96(1), 69-74.

38 S. Das, J. Das, A. Samadder, S. S. Bhattacharyya, D. Das and A. R. Khuda-Bukhsh, Biosynthesized silver nanoparticles by ethanolic extracts of Phytolacca decandra, Gelsemium sempervirens, Hydrastis Canadensis and Thuja occidentalis induce differential cytotoxicity through G2/M arrest in A375 cells, Colloids Surf., B, 2013, 101, 325-336.

39 T. Shanmugasundaram, M. Radhakrishnan, V. Gopikrishnan, R. Pazhanimurugan and R. Balagurunathan, A study on the bactericidal, anti-biofouling, cytotoxic and antioxidant properties of actinobacterial synthesized silver nanoparticles, Colloids Surf., B, 2013, 111, 680-687.

40 A. Gole, C. Dash, V. Ramakrishnan, S. R. Sainkar, A. B. Mandale, et al., Pepsin-gold colloid conjugates: Preparation, characterization and enzyme activity, Langmuir, 2001, 17, 1674-1679.

41 D. Raghunandan, B. D. Mahesh, S. Basavaraja, S. D. Balaji, S. Y. Manjunath and A. Venkataraman, Microwave-assisted rapid extracellular synthesis of stable bio-functionalized silver nanoparticles from guava (Psidium guajava) leaf extract, J. Nanopart. Res., 2011, 13(5), 2021-2028.

42 Q. L. Feng, J. Wu, G. Q. Chen, F. Z. Cui, T. N. Kim and J. O. Kim, A mechanistic study of the antibacterial effect of silver ions on Escherichia coli and Staphylococcus aureus, J. Biomed. Mater. Res., 2008, 52, 662-668.

43 I. Sondi and B. Salopek-Sondi, Silver nanoparticles as antimicrobial agent: a case study on $E$. coli as a model for Gram-negative bacteria, J. Colloid Interface Sci., 2004, 275, 177-182.

44 K. B. Holt and A. J. Bard, Interaction of silver (I) ions with the respiratory chain of Escherichia coli: an electrochemical and scanning electrochemical microscopy study of the antimicrobial mechanism of micromolar $\mathrm{Ag}^{+}$, Biochemistry, 2005, 44, 13214-13223.
45 P. V. Vignais, The superoxide-generating NADPH oxidase: structural aspects and activation mechanism, Cell. Mol. Life Sci., 2002, 59(9), 1428-1459.

46 S. Ninganagouda, V. Rathod, D. Singh, J. Hiremath, A. K. Singh, J. Mathew and M. ul-Haq, Growth kinetics and mechanistic action of reactive oxygen species released by silver nanoparticles from Aspergillus niger on Escherichia coli, BioMed Res. Int., 2014, 1-9, DOI: 10.1155/2014/753419.

47 G. V. Smirnova and O. N. Oktyabrsky, Glutathione in Bacteria, Biochemistry, 2005, 70(11), 1199-1211.

48 H. Xu, F. Qu, H. Xu, W. Lai, Y. Andrew Wang, Z. P. Aguilar and $H$. Wei, Role of reactive oxygen species in the antibacterial mechanism of silver nanoparticles on Escherichia coli O157:H7, BioMetals, 2012, 25(1), 45-53, DOI: $10.1007 / \mathrm{s} 10534-011-9482-x$.

49 S. M. Hussain, K. L. Hess, J. M. Gearhart, K. T. Geiss and J. J. Schlager, In vitro toxicity of nanoparticles in BRL 3A rat liver cells, Toxicol. In Vitro, 2005, 19(7), 975-983.

50 L. Braydich-Stolle, S. Hussain, J. J. Schlager and M. C. Hofmann, In vitro cytotoxicity of nanoparticles in mammalian germline stem cells, Toxicol. Sci., 2005, 88, 412-419.

51 ATSDR (Agency for toxic substances and Disease Registry), Toxicological profile for Silver, Prepared by Clement international corporation, under Contract 205-88-0608, U.S. Public Health Service, 1990, ATSDR/TP-90-24.

52 C. Carlson, S. M. Hussain, A. M. Schrand, K. Braydich-Stolle, K. L. Hess, R. L. Jones and J. J. Schlager, Unique cellular interaction of silver nanoparticles: size-dependent generation of reactive oxygen species, J. Phys. Chem. B, 2008, 112(43), 13608-13619.

53 M. Schuler, E. Bossy-Wetzel, J. C. Goldstein, P. Fitzgerald and D. R. Green, p53 induces apoptosis by caspase activation through mitochondrial cytochrome c release, $J$. Biol. Chem., 2000, 275(10), 7337-7342.

54 M. S. Greenblatt, W. P. Bennet, M. Hollstein and C. C. Harris, Mutations in the p53 tumor suppressor gene: clues to cancer etiology and molecular pathogenesis, Cancer Res., 1994, 54, 4855.

55 K. Oda, H. Arakawa, T. Tanaka, K. Matsuda, C. Tanikawa, T. Mori, H. Nishimori, K. Tamai, T. Tokino, Y. Nakamura and Y. Taya, p53AIP1, a potential mediator of p53dependent apoptosis, and its regulation by Ser-46phosphorylated p53, Cell, 2000, 102(6), 849-862.

56 G. Y. Liou and P. Storz, Reactive oxygen species in cancer, Free Radic. Res., 2010, 44, 479-496. 